ӘОЖ 811.512 .1

FTAXP 16.41.25

DOI 10.37238/1680-0761.2021.83(3).11

\author{
Салқынбай А.Б.*, Каспихан Б.К. \\ әл-Фараби атындағы Қазақ ұлттық университеті, Алматы, Қазақстан \\ *Корреспондент авторы: asalkbek@gmail.com
}

E-mail: asalkbek@gmail.com, b.kaspikhan@gmail.com

\title{
КӨНЕ ТУРКІ ЖАЗБА ЕСКЕРТКІШТЕРІНДЕГІ «ӨМІР» КОНЦЕПТІСІ
}

\begin{abstract}
Аңдатпа. Мақ̆алада көне түркі жазба ескерткіштеріндегі «Өмір» концептісі талданады. Жазба ескерткіштердегі «Өмір», «Өлім»концептілерінің репрезентациялануы, көне түркі жазба ескерткіштерінің танымдық тұрвыда зерттелуі сөз болады. Адамзат танымындавы «Өмір авашы» ұzымының түркі халықтарының когнитивтік әлемінде «Өмір» конщептісінің, қасиетті күштер мен құдайлар пантеонының, түркі танымындавы үш түрлі әлемнің моделі болатындывы баяндалады. Көне түркі жазба мұраларында Жерасты әлемін Еркілік басқарса, Ортаңзвы әлемде Ұмай ана мен құасиетті Жер-Судың болатынын, Жовары әлемде көк Тәңірінің басқаратынын көруге болады. Ескерткіш мәтіндерінде «Өлім» конщептісін öltig, adïriltïm, kärgäk bol, ис̆а bar сияқть тілдік бірліктер құрайды. Көне түркі жазба ескерткіштері материалдары негізінде түркілердің өлім туральы философияльқ ойлары жүйеленіп, түркі халықтарының дүниетанымы этнолингвистикалық тұрzыла зерделенеді.
\end{abstract}

Кілт сөздер: көне түркі ескерткіштері; Өмір авашы; концепт; өмір; өлім.

\section{Kipicne}

Көне түркі жазба ескерткіштері бүкіл әлемге жария болып, дат ғалымы В.Томсен түркі жазуының «кілтін» тапқаннан бастап, жан-жақты зерттелініп келеді. Көне түркі жазба ескерткіштері арқылы түркі тілдерінің фонетикалық жүйесі, грамматикасы туралы, ескерткіш мәтіндерінің аудармалары туралы, көне түркі жазуының шығу тегі туралы көптеген ғылыми еңбектер жарық көрді. Сонымен қатар тіл білімінде көне түркі жазбаларын лингвофилософиялық, лингвокогнитивтік, дискурстық тұрғыда талдау қолға алынуда.Осы тұрғыда ескерткіш мәтіндеріндегі басты концептілерді талдау түркілердің танымдық табиғатын тануға, түркі тіліндегі «ғаламның тілдік бейнесін» түсінуге жол ашады.

Түркі жазба ескерткіштері құрылымдық бағытта зерттелген кезеңде де ғалымдар түркілердің діни сенімдері мен мифологиялық жүйесі туралы мақалалар жариялаған. Мәселен, И.В. Стеблева көне түркі жазба ескерткіштеріндегі діни-мифологиялық жүйе туралы мақаласында Täqri, Umaj, Yduq jär sub туралы жазып, түркі танымындағы бинарлық қатынастарды талдайды.Ғалым түркілердегі құдіретті күштерді төрт түрлі деңгейге бөледі: 1) Täqri - Тәңір; 2) Umaj - Ұмай ана; 3) Yduq jär sub - Қасиетті Жер-Су; 4) Ата-баба аруақтары [1]. Ал С.Г. Кляшторный болса, түркілер танымында үш түрлі әлем бар екендігін, Төменгі жерасты әлемін Еркіліктің басқаратынын, Тәңірдің тағдырды жазып, өмірді бөліп беретінін, Ұмай ананың «адам баласының» дүниеге келуіне, ал олардың дүниеден өтуіне Еркіліктің жауап беретінін жазады [2, б. 131].

Түркі тілдеріндегі «ғалам бейнесі» туралы Ресей ғалымдары «В настоящее время аксиоматический характер приобретает тезис: картина мира в представлениях не только 
тюркских, но и алтайских, а также уральских народов кардинально отличается от привычных европейских схем. Этот тезис требует, однако, развернутого подтверждения на конкретном материале» деп жазады [3, б. 662]. Түркі халықтарының дүниетанымдық көзқарастарын танып-білу үшін түркі жазба ескерткіштеріндегі, түркі фольклоры мен мифологиясындағы деректерді пайдалана отырып, басты концептілерді анықтауға, талдауға болады.

Профессор Н.Г. Шаймердинова көне түркі жазба ескерткіштерін когнитивтік, дискурстық тұрғыдан зерттеп, Тоныкөк феномені, түркі ескерткіштеріндегі уақыт пен кеңістік категориясы туралы жазады. Ғалым көне түркі ескерткіштерін зерттеген ғалымдарды прецедентті тұлға ретінде қарастырып, олардың аудармасындағы ерекшеліктерді талдайды. Ғалым «Вовсе не случайно смерть каганов и Кюль-тегина выражается нетипичными глаголами «улетел», «отлетел», а доминантный для данной ситуации глагол «умер» употребляется в скобках. В указанных глаголах («улетел», «отлетел») содержится глубинный смысл: видимо, для древних тюрков смерть имела другую интерпретацию, смерти как таковой не было, смерть - это бессмертие или продолжение жизни в макрокосмосе» деп жазады [4, б. 70]. Осы жерден түркі танымындағы «Өмір», «Өлім» концептілерін талдаудың маңыздылығын көреміз.

\section{Зерттеу материалдары мен ддістері}

Көне түркі жазба ескерткіштерін жаңа антропоөзектік парадигма аясында зерделеу түркілердің танымдық ерекшеліктерін, когнитивтік әлемін түсінуге жол ашады. Көне түркі жазба мұраларындағы материалдар негізінде алғашқы этнолингвистикалық бағыттағы ойларды П.М. Мелиоранский, С.Е. Малов еңбектерінен, түс атауларының семантикасын талдаған А.Н. Кононов еңбектерінен, И.В. Стеблева мен С.Г. Кляшорный мақалаларынан көруге болады. Көне түркі жазба ескерткіштеріндегі «Өмір» концептісін талдау барысында Орхон, Енисей, Талас ескерткіштерінің материалдарын пайдаландық. Ортағасырлық түркілердің танымынан мәлімет беретін Күлтегін ескерткішінің үлкен (КТб) және кіші жазуларын (КТм), бұрыштағы жазуларын (К I, II), Тоныкөк ескерткішін (Тон), Енисей бойынан табылған эпитафиялық ескерткіштерді, атап айтқанда Уюк-Туран ескерткіші (Е3) менБарық-II (E6), Бегре (E11), Қызыл-Чыраа I (E43), Көжелік-Қобы (E45), Теле (E46), ЧерЧарык (Е69) ескерткіш мәтіндерін, Талас ескерткіштерінің ішінен Айртам-Ой (Т4) ескерткішінің мәтіндерін пайдаландық. Талдау барысында А.С. Аманжолов аудармаларын басты негізге алдық. Жұмыста белгілі бір кезеңге синхронды түрде сипаттама жасалып, жинақтау, когнитивтік және аналитикалық талдаудың түрлері мен тәсілдері пайдаланылды.

\section{Зерттеу нәтижелері}

С.А. Жиренов концепт терминіне «Концепт - тіл мен таным бірлестігі арқылы дүниені жан-жақты тануға, сонымен қатар ұлттық-танымдық мәдениетті зерделеп ұғынуға ықпал ететін, адам санасында жинақталған аялық білімнің шоғыры, тілдік-танымдық бірлік» деген анықтама береді [5, б. 8].

Көне түркі жазба ескерткіштеріндегі метафораларды зерттеген ғалым Ж.А. Абитжанова Орхон-Енисей ескерткіштеріндегі концептілерді «Өмір», «Соғыс», «Қамығу», «Сенім», т.б. деп топтастып, «Өмір концептісін құрайтын тілдік тұлғалар: он оқ, токуз татар, бұйрық бектер, Үч тувльг түрк, Елтеріс, Елбілге, Ұмай, Тәнуір, Кюли Чор, bakir, кара қуш, барыс, жылан, бура, құт, ілгерү, құара будун, mirig, тоқылыbы, учды т.б.» деп жазады [6, б. 18].

Адамзат баласына ортақ «Өмір» концептісін түсіну үшін оны қарама-қарсы мағынадағы «Өлім» концептісімен салыстырып қарау керек. «Өмір» макроконцептісінің өзі «Тәңір», «Тағдыр», «Уақыт», «Дүние» сияқты концептілерден тұрады.

Қазақ тілінің түсіндірме сөздігінде «Өмір» ұғымына «Өмір. 1. Материяның қозғалу, даму, өсу көріністерінің жалпы жиынтығы, тіршілік. 2. Адам мен жан-жануарлардың, өсімдіктердің физиологиялық тіршілік ету, өсу процесі. 3. Өсу, даму процесінің белгілі бір кезеңі, сатысы; тірі организмнің тіршілік ету мерзімі; ғұмыр» деген анықтама беріледі [7, б. 653]. 
Түркі танымындағы «Өмір» концептісі әлемдік философиядағы «Өмір ағашы», «Тәңір ағашы» категорияларымен байланысты. Түркі халықтарының дүниетанымындағы «Өмір», «Тәңір», «Дүние» сияқты концептілердің графикалық бейнесі «Тәңір ағашы» болатынын сеніммен айтуға болады.

Қазақ мифологиясын зерттеуші С.Қондыбай «Ғаламдық ағаш» туралы «Тік тұрпат (вертикаль) бойынша Ғаламдық ағаш үш деңгейден (төменгі - тамыр, ортаңғы - дің, жоғарғы - бұтақтар мен жапырақтар) тұрады, олар реттелген ғаламның вертикаль моделін (тернарлық моделін немесе триграмманы) көрсете алады» дейді [8, б. 486].

«Өмір» концептісі адам баласының дүниеге келуі, адам баласының жаратылуымен

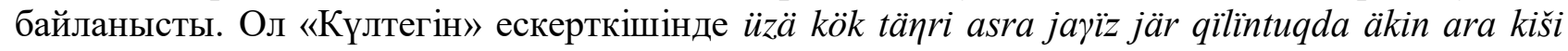

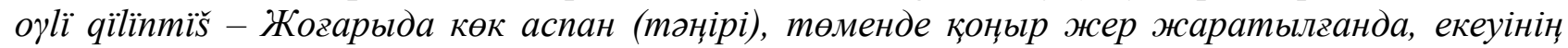
арасында адам баласы жаратылван (КТб. 1) [9, б. 199]деген жолдардан көрінеді.

Көк аспан мен қара жерді жерді байланыстыратын ағаш өмір жалғастығының, ұрпақ сабақтастығыныңбелгісі, сол себепті «Өмір ағашы» деп те аталады. Қазақ шежіресінде де генеологиялық кестені ағаш түрінде беруі тегін емес. Ағаштың тереңге тартқан тамыры атабабаларды, түптамырды көрсетсе, жоғары өрлеген бұтақтар ұрпақ жалғастығын, өркен жайған, өскен, өрбіген үрім-бұтақты бейнелейді. Түркілердің мифтерінен Кейінірек жер жүзінде товыз бұтавы бар бір аваш жаратты. Сосын әр бұтақтың астында бір адам жаратты. Бұлар дүниедегі тогыз адамның аталары болды деген сюжеттерді кездестіреміз [10, б. 18]. Қазақ тілінде үбірлі-шүбірлі бол, үрім-бұтавың мол болсын деп бата беріп, тілек айтуы «Өмір» мен «Өмір ағашы» моделінің байланысын көрсетсе керек.

«Өмір» концептісін түсіну үшін түркі халықтарының дүниетанымындағы «Тәңір» концептісінің құрылымымен таныс болу керек. «Тәңір» концептісі «Өмір ағашы» («Тәңір ағашы») арқылы түркі танымындағы үш түрлі әлем моделі арқылы түсіндіріледі. «Өмір ағашы» арқылы бейнеленген үш түрлі әлем моделі адамзат баласына ортақ мифологиялық сюжеттерге құрылған. Осындай үштік модельді ежелгі грек, иран өркениетінен де, алтай аңыздарынан да көреміз. Ш.Уәлиханов өз еңбектерінде аспанда тұратын адамдар белбеуді тамағынан буынады, біз, ортасында тұратындар, белімізге байлаймыз, ал жер астындағылар белбеуді аяқтарына буынады деп қазақ аңыздарындағы үш түрлі әлем сюжетін баяндайды [11, б. 185]. Көне түркі жазба ескерткіштерінде үш түрлі әлем нақты көрсетілмесе де, түркі халықтарының мифтері мен аңыздарын пайдалана отырып, үш түрлі әлем моделін құрастыруға болады.

Ағаштың тамыры жер асты әлемін көрсетеді. Жер асты әлемінің билеушісі - Еркілік. Көк аспан мен қара жер ескерткіштерде жиі айтылса, жер асты әлемі туралы ақпаратты түркі халықтарының аңыздары мен мифтерінен ғана кездестіреміз. С.Г. Кляшторный Еркілік (Erklig/Erlig) есімін қырғыз қағаны Ынанчу Алп Білгенің эпитафиясынан (Алтынкөлдің бірінші ескерткішінің сегізінші жолынан), Шығыс Түркістандағы Дуньхуаннан табылған «Ырық бітігтен» табады. Ғалым Еркілік есімін «Ырық бітігтің» үш жерінен кездестіргенін айтады [2, б. 127]. С.Қондыбай Еркілікті қазақтың «Ер Төстік» ертегісіндегі Темірханмен байланыстырады [12, б. 167]. Түркінің «Жаратылыс» дастанында: ...Қайра хан Ерлігтің дүниесін ең төменгі құабатқ̧а орнықтырды. Ол жерде күн, ай мен жұлдыздың да сәулесі

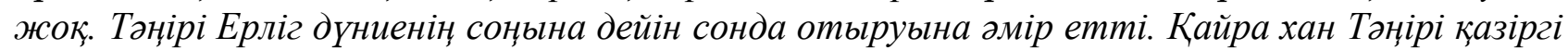
кезде көктің он жетінші құабатынан жаратылысты басқарып отыр деген аңыз бар [10, б. 19]. Алтай түркілерінен В.В. Радлов жазып алған осы аңыз жер асты әлемін басқарған Еркілік туралы ойды дәлелдей түседі.

Ортаңғы әлемді Ұмай ана және қасиетті Жер-Сумен байланыстыруға болады.Ұмай ана түркілер танымында балалардың қорғаны, Тәңірі, қасиетті Жер-Сумен бірге түркі халқына құт беретін, қолдау көрсететін қасиетті күштердің бірі. Алтай түркілері баланы Ұмай/Ымай желеп-жебеп, қорғап жүреді деп есептеген. П.М. Мелиоранский «Из других столь многочисленных обыкновенно у шаманистов божеств в надписях называется только 
Умай женское божество, известное до сих пор на алтае у шорцев; теперь Умай считается покровительницей детей» деп жазады [13, б. 266]. Ж.Абитжанова Umaj сөзі «бала жататын орын» деген тура мағынадан «бала-шағаны қорғайтын құдай» деген екіншілік номинация қалыптасқанын айтады [6, б. 19]. Ескерткіш мәтіндеріненаналарын Ұмай анаға теңеген uтај täg ögim qatun quẗ̈а inim kül tigin är at bultï - Ұмай сияқты анам хатұнның бавына, інім Күлтегін ер атанды (КТб. 31) [9, б. 203] деген жолдарды және жеңіс сыйлайтын, құт беретін Ұмай ана туралы tänri umaj ïduq jär sub basa bärti ärinč. - Тәңірі, Ұмай, қ̧асиетті Жер-су бізге жеңзіс сыйлады емес пе (Тон. 38) [9, б. 219] деген жолдарды кездестіруге болады.М.Қ. ЕскееваҰмай лексемасын «өмір мен тіршілік», «денсаулық пен салауаттылық», «әдемілік пен әсемдік», «бақыт пен ырыс», «өнер мен білім», «жеңіс пен сәттілік» тәрізді құндылықтар сыйлаушы кие, пір мәнін сақтаған тілдік репрезентациясы деп есептейді [14, б. 207].

Түркілер жоғары әлемді басқаратын, жалғыз жаратушы деп көктегі Тәңірді қабылдайды. Түріктің білікті қағандарын да Тәңір қояды, түркі халқының өсуі де, соғыстарда жеңіске жетуі де тәңірге байланысты. Оны ескерткіштердегі türk bodunїу atï küsi joq bolmazun

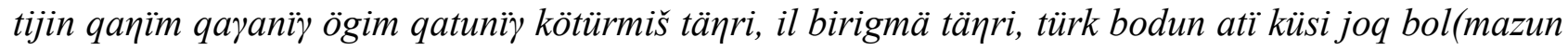

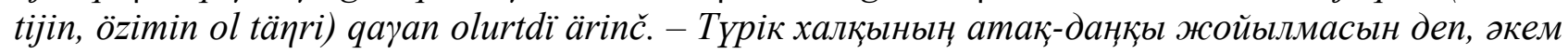
қ̧аванды, анам хатұнды көтерген тәңірі, ел берген тәңірі, түрік халқының атақ-даңқы жойылмасын деп, өзімді сол тәнуірі қ̧аван етіп (таққа) отырвызды (КТб. 25-26) [9, б. 202]

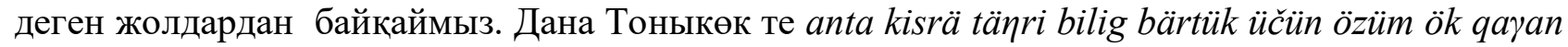
qїsdiт - Сонан кейін тәнірі ақыл-білім бергені үшін, өзім-ақ қаван етіп сайладым (Тон. 6) [9, б. 216] деп ақыл-білімді де берген тәңірі екенін тасқа қашап кеткен.

«Өмір» концептісі «Тағдыр» концептісімен тығыз байланысты. Түркілердің танымында адам баласына тағдырды жазып, уақытты бөліп беретін Тәңір екендігін ескерткіш мәтіндерінен аңғарамыз. «Күлтегін» ескерткішіндегіöd täqri jasar, kiši oylï kop ölgäli törümiš(КТб, 50) деген жолды Ғ.Айдаров Уақыттыь Тәңірі жасар, адам баласының бәрі өлгелі туван деп [15, б. 182], М.Жолдасбеков Тавдырды тәнірі жасар. Адам баласының бәрі өлгелі тузан деп [16, б. 57], ал А.Аманжолов Адам баласының бәрі өлмек үшін туван. Мәңзгілік уақыт Тәңірі вана жасар деп аударады [9, б. 204]. Осы жерден ӧd сөзінің уақытпен қатар mazdыр деген мағынаны да бергенін байқаймыз. Кейін ислам діні келуімен қазақ дүниетанымында араб тілінен тавдыр лексемасы орнығады $[17,6.16]$. Ескерткіштің осы бір жолында түркілердің өмірдің қарапайым философиясын, өзекті жанга өлім бар екенін түсінгенін көреміз.

«Өмір» концептісін «Өлім» концептісімен қатар қойғанда ғана толық тану мүмкін болады.«Өлім» концептісін öltig, adïriltïm, kärgäk bol, uča bar сияқты тілдік бірліктер құрайды. Öl етістігін көк түріктер барлық тіршілік иелеріне қатысты қолданған. Түркілер бүкіл халықтың жойылып бара жатқанын süčig sabïna jïmšaq aүïsïna arturïp üküš türk bodun öltig - Тәтті сөзіне, жавымды сыйына алдатқызыып, көп түрік халқыь, өлдіңң! (КТм. 6) [9, б. 187] деп, Күлтегіннің тұлпарларының мерт болғанын даbir otuz jašïna čača säqunkä

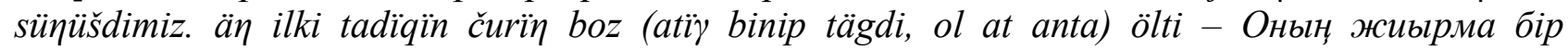
жасында Чача сенгүнмен совыстық. Ең алдымен Тадықыын-Чур ақббозатына мініп, шабуылдадыл... (Ол ат сол жерде) өлді (КТб. 32-33) [9, б. 203] деп ӧl сөзін қолданған.

Көне түркі жазба ескерткіштерінде «Өлім» концептісі kärgäk bol тілдік бірлігі арқылы да берілген. Мәселен, оны ескерткіштердегі ӧzіnčä kärgäk bolmïš - Өздері (кейіннен) дүние салван (КТб. 3) [9, б. 200] және išig küčig birür bunča törüg qazүanïp inim kül tigin özinčä kärgäk bolti. - Күш-қуатын сарп етіп, осынша елді иеленіп, інім Күлтегін өзі дүние салдыл (КТб. 30) [9, б. 202] деген жолдардан көре аламыз. «Өлім» концептісінің көне түркі жазба ескерткіштерінде репрезентациялануын кестеден көре аламыз (Кесте). 
1 - Кесте - «Өлім» концептісі

\begin{tabular}{|c|c|c|}
\hline № & Логикалық моделі & Тілдік моделі \\
\hline 1 & $\begin{array}{l}\text { Өлімнен қ̧ашыл } \quad \text { құтыла } \\
\text { алмайсың. }\end{array}$ & $\begin{array}{l}\text { öd tänri jasar, kiši oүli kop ölgäli törümiš. - Время (сроки) } \\
\text { распределяет Тенгри (властелин Неба, бог), люди же } \\
\text { все рождены с тем, чтобы умереть. (КТб. 50) }\end{array}$ \\
\hline 2 & $\begin{array}{l}\text { Өлім/Ажал } \quad-\quad \text { тәңірдің } \\
\text { бұйрывы. }\end{array}$ & 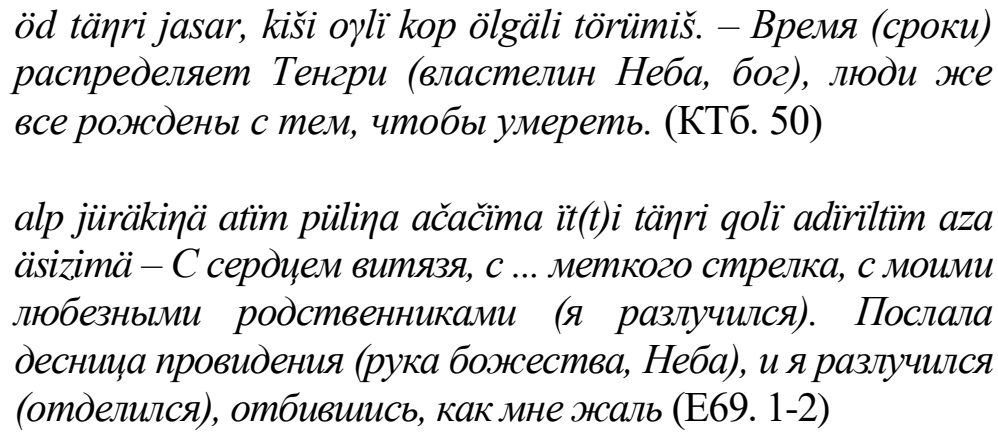 \\
\hline 3 & $\begin{array}{l}\text { Өлім - мұңсыз, қ̧айдысыıы } \\
\text { әлем. }\end{array}$ & 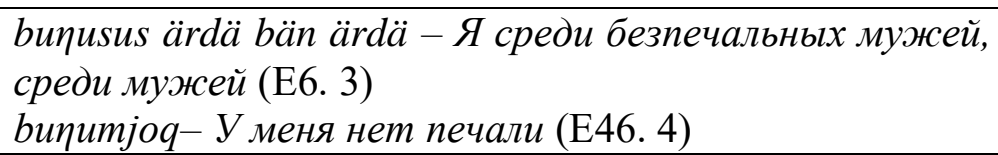 \\
\hline 4 & $\begin{array}{l}\text { Өлім - жақыныңнан, туган } \\
\text { жеріңнен, жарық олемнен } \\
\text { айырылу. }\end{array}$ & 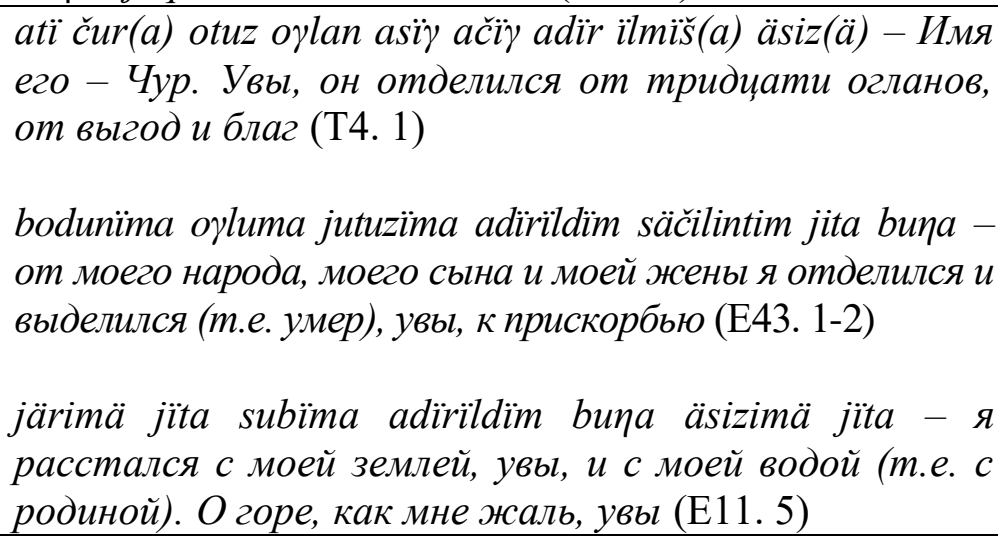 \\
\hline 5 & $\begin{array}{l}\text { Өлім - күн мен айдыл, } \\
\text { жарықты көрмеу. }\end{array}$ & 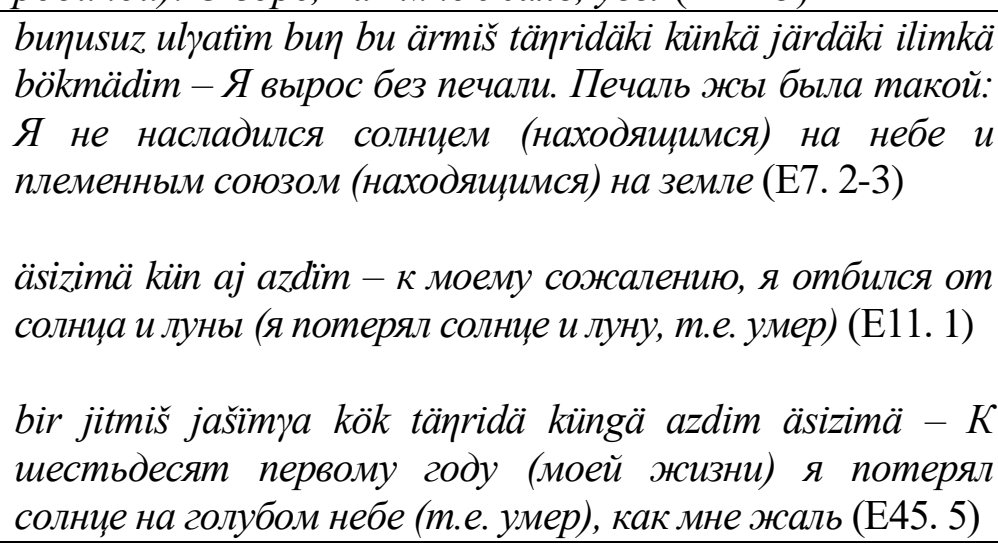 \\
\hline 6 & 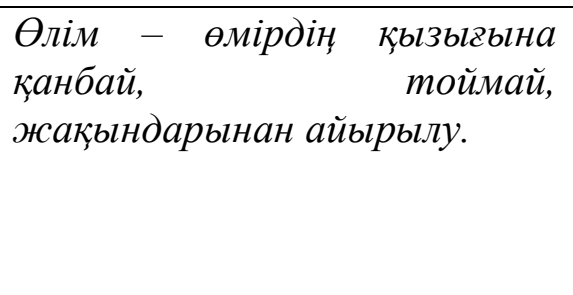 & 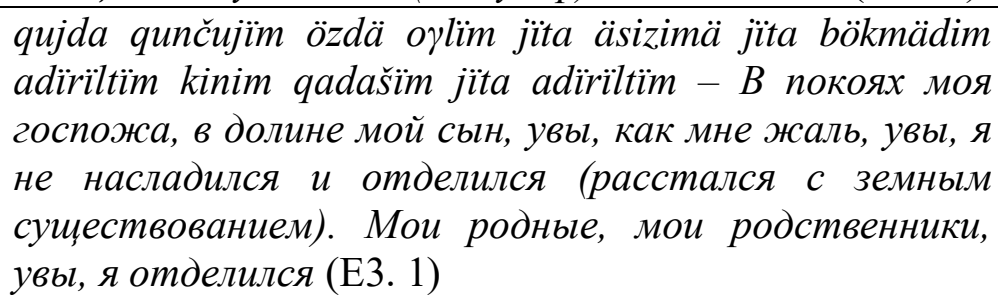 \\
\hline
\end{tabular}


Көбінесе эпитафиялық ескерткіштерде «Өлім» концептісі adïrïtïm бірлігі арқылы

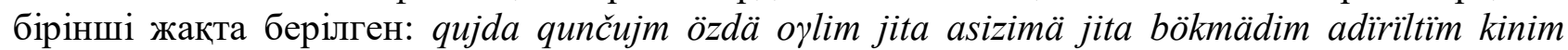
qadïsïm jita adïriltïm- Үйде ханымым, түзде ұлым, қ̧айран, қ̧андай өкінішті, бөгіп тойынбадым, айырылдым, кіндіктесім, құндас туысым, қайран, айырылдымм (Е3. ) [9, б. 180] немесе quјdaqï quпс̌ијїна adïrildïm арата- Үйдегі ханымымнан, апамнан айырылдым (Е6.) [9, 180]. ДТС-те осы етістікке «adïrïl- страд. от adïr- 1. быть отделенным; 2. Отделяться, расставаться, разлучиться; 3. перен. Отделиться, разлучиться (в знач. умереть)» деген анықтама беріледі [18, б. 12]. Бұл сөз ажырау, айырылу, бөлініп шығу мағынасындағы $a m$ түбіртегінен жасалған. Мәтіндерде осы сөз жақындарын тастап, басқа әлемге өткенін көрсетумен қатар, адам бойындағы жан мен тәннің ажырағанын да көрсетсе керек. Осы жерде Абайдың:

Өлсе өлер табиват, адам өлмес,

Ол бірақ̧ құайтып келіп, ойнап-күлмес.

«Мені» мен «менікінің» айрылганын

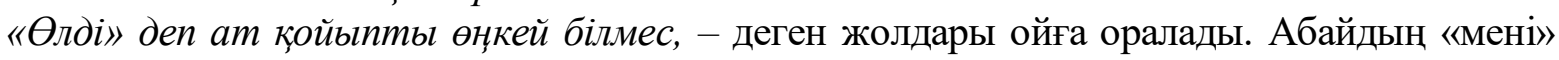
мен «менікі» деп отырған жан мен тән деген терең философиялық ой көне түркі танымында бар. Оны көне түркі жазба ескерткіштеріндегі «Өлім» концептісінің ис̆а bar деген тілдік бірлігінен анық көреміз. Адам дүниеден өткен кезде оның жанының жоғарыға ұшуы, тәңірге қайтуы, түркі танымындағы үш түрлі әлем моделін дәлелдей түседі. Жоғарыға ұшып жалғандықтың мәңгілікке айналуы түркілердің терең философиялық ойларын көрсетке керек. Ескерткіштерде

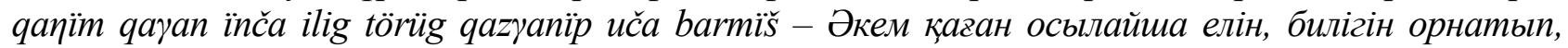
ұшыл кетmi (дүние салды) (КТб. 15-16) [9, б. 201] деген жолдарда, асыл бектерге, қағандарға қатысты ис̆a barmï̌ деген тілдік бірлік қолданылса, жанның мекені көкте екенін мынадай

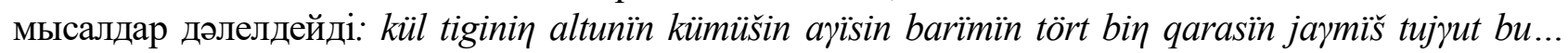
bägim tägin jögärü täqri... taš bitidim jollïү tigin - Принадлежащие (т.е. посвященное) Кюльтегину золото и серебро, его драгоценности, имущество, четыре (тысячи голов?) ското принесли в жертву. Туйгуныл... Мой герой, тегин (прини), вверху (на Небе)... На камне я написал, Йолльлг-тегин (К І.) [19, б. 174] немесе bunča bitig bitigmä kül tigin atïsï jolluү tigin bitidim. jigirmi

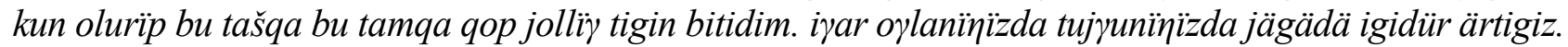

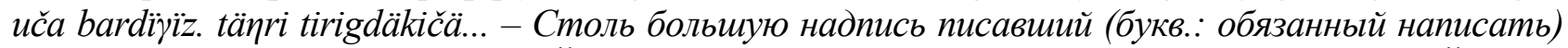
родной племянник Кюль-тегина, Йолльг-тегин, я написал. В течение двадиати дней я, Йолльгтегин, полностью написал (ее) на этом камне и на этой стене. Bы возвышали (лучших) из ваших верных огланов (сыновей) ваших туйгунов (удалых молодиов). Вы улетели и (теперь) подобны небожсителям... (К II.) [19, б. 174].

А.Аманжолов Батыс Қазақстан облысынан табылған сасанидтер дәуірінде жасалған

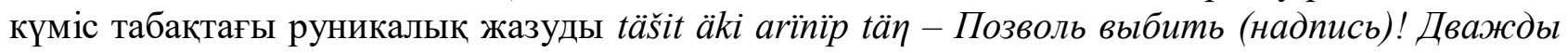
очищаясь, взлети! деп оқып, ол туралы «Данная ритуальная формула, по-видимому, представляет собой обращение к душе покойного, хозяина данного блюда» деген қорытынды жасайды [19, б. 253]. Жайық бойынан табылған осы эпиграфикалық ескерткіштен де түркі танымында жанның тазарып, жоғарыға көтерілетіні туралы сенім болғандығын көреміз.

М.Қ. Ескеева өз еңбегінде «Көк Тәңірі» рухтың, жанның, ішкі мазмұнның иесі, уақытқа тәуелсіз мәңгіліктің символы ретінде басымдыққа ие болса, «Жер» тәнді, денені, ішкі мазмұнның сыртқы тұлғасын қалыптастырушы ретінде «бұл дүниенің жалғандығын» танытады да, екеуі бірігіп тұлға мен мазмұнның бірлігін, мәңгілік пен жалғандықтың (уақытта тәуелді биожаратылымның ғұмыры) қайшылығын сипаттайды» деп жазады [14, б. 185].

Түркілердің өлім туралы ажалы жеткенде «мені» мен «менікінің» айырылып, адамның тәні ағаштың тамыры сияқты жер қойнына кетсе, таңдаулы адамдардың жаны жоғары қарай өрлеп, мәңгілік субстанцияға айналады деген терең философиясын көне түркі жазба ескерткіштері арқылы білуге болады. 

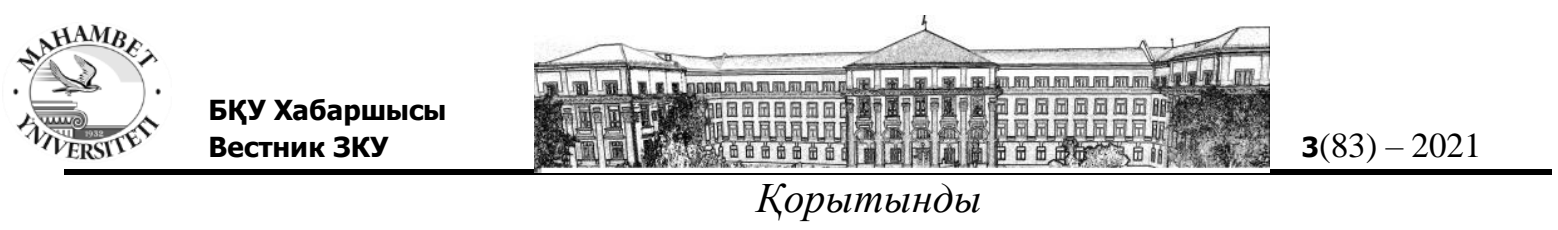

Түркі жазба мұраларындағы «Өмір» концептісінің «Тәңір ағашы» моделіндегі көрінісі ескерткіш материалдарындағы тілдік деректермен қатар, фольклорлық шығармалар арқылы да, археологиялық материалдар арқылы да дәлелдене түседі.

А.К. Акишев Есік қорғанынан табылған алтын киімді адамның бас киімі «Өмір ағашы» концепциясының көрінісі деп есептеп, «Символика деления декора по вертикали и иконическое подразделение животных (бескрылый - крылатый) на всех трех частях золотого костюма отражали пространственную ткань мифов и соответствующие отношения между образами композиции» деп жазады[20, б. 18]. Алайда зерттеуші мұны индоирандықтардан келген деп санайды. Осы қорғаннан табылған «Есік жазуы» аталған руникалық жазуды ирантілдес деп есептеу, сақтардың танымындағы «Өмір ағашының» индоиран халықтарынан келді деп тану еуропацентристік көзқарас, жаңсақ пікір болса керек. «Өмір ағашы /Тәңір ағашы» моделі адамзат баласының бәріне ортақ, оны көптеген өркениеттердің іздерінен байқай аламыз, сондай-ақ түркі мұраларынан «Өмір ағашы» моделінің кірме еместігі, оның түркі философиясын метафоралы түрде көрсететіні анық.

Космографиялық жүйеде құстар жоғары әлемді, балықтар, жыртқыш аңдар, бауырымен жорғалаушылар мен кеміргіштер жерасты әлемін, тұяқты жануарлар ортаңғы әлемді бейнелейді. Осындай үш түрлі әлемді бейнелейтін «Өмір ағашы» моделінің ғұрыптық ескерткіштерде көрінісі туралы В.Е. Войтов «На ряде каганско-княжеских поминальных комплексов сохранились статуи черепах, львов и баранов, которые в трехчленной зоологической классификации макрокосма должны соответствовать Нижнему и Среднему мирам»дейді [21, б. 75]. Осы жерде қазақ ертегілеріндегі жерастындағы жылан Бапы ханның елі туралы сюжетпен салыстырыңыз.

Пазырық қорғанынан табылған кілемшедегі фрагментте қолында өркен жайған ағаш ұстаған тақтағы әйел құдай бейнесі мен салт атты бейнеленген [21, б. 67]. Осы фрагменттен де ұрпақ жалғастығы, өмір сабақтастығы тарайтын ана бейнесін, «Өмір ағашын» көруге болады. Фрагменттің түркі ескерткіштері мен мифтеріндегі Ұмай ана бейнесімен байланысын байқаймыз.

Т.Зәкенұлы «Қазақтың «Қозы Көрпеш - Баян сұлу» жырында тәңір ағашын «мықан ағашы» деп атаған. Бұл байырғы түркі түсінігіндегі киелі ағаш. Ертеде халық арасында Жер мен Көктің арасын жалғастырушы құдіретті күш осы ағашқа қонақтаған деген түсінік болған. Монғол жеріндегі Білге қаған кешенін қазған кезде қаған барқының (храмының) артындағы шарбақтастың дәл ортасынан тік қадалған ағаш табылды. Дәл осындай анологтар Тоң-ұқұқ, Цаған-дова (Монғолия) ескерткіштерінен және Сібірден көп кездеседі» деп жазады [22, б. 333].

Осы деректердің барлығы түркі дүниетанымындағы «Өмір» концептісінің түркі космографиясының, түркілердің үш түрлі әлем туралы түсінігін, өмірдің ортаңғы әлеммен байланысын, ал өлімнің жоғарыдағы көк аспан мен төмендегі жерасты әлемімен байланысын айғақтайды. «Өмір» мен «Өлім» концептілері арқылы түркі халықтарының дүниенің құрылымы туралы танымдық әлемін түсіне аламыз.

\section{ӘДЕБИЕТ}

[1] Стеблева И.В. К реконструкции древнеюркской религиозно-мифологической системь / И.В. Стеблева // Тюркологический сборник. 1971. - Москва: Наука, 1972. - С. 213-226.

[2] Кляшторный С.Г. Мифологические сюжеты в древнетюркских памятниках / С.Г. Кляшторный // Тюркологический сборник. 1977. - Москва: Наука, 1981. - С. 117-138.

[3] Сравнительно-историческая грамматика тюркских языков. Пратюркский языкоснова. Картина мира пратюркского этноса по данным языка / отв. ред. Э.Р. Тенишев, А.В. Дьбо. - Москва: Наука, 2006. - 908 с. 
[4] Шаймердинова Н.Г. Древнетюркская картина мира в текстах письменных памятников: учеб пос. / Н.Г. Шаймердинова. - Астана: ЕНУ, 2014. - 261 с.

[5] Жиренов С.A. XV-XIV в.z. ақын-жьраулар поэзиясындавы «Өмір-Өлім» концептісінің танымдық табиватыл: «10.02.02 - Қазақ тілі» маман. филол.выл.канд. дисс. авторефераты / С.А. Жиренов. - Алматы, 2007. - 30 б.

[6] Абитжанова Ж.А. Орхон-Енисей ескерткіштері тіліндегі метафоралардың уәжділігі мен семантикасы: «10.02.06 - Түркі тілдері» маман. филол.выл.канд. дисс. авторефератьл / Ж.А. Абитжанова. - Алматы, 2009. - 24 б.

[7] Қазақ тілінің түсіндірме сөздігі / жалпь ред. басқ.. Т. Жанұзақ̧ов. - Алматы: Дайк-Пресс, 2008. - 968 б.

[8] Қондыбай С. Тольқ шывармалар жинавы. 12-том. Арвықазақ мифологиясы. 4кітап / С. Қондыбай. - Алматы: Арыс, 2008. - 536 б.

[9] Аманжолов А.С. ТҮркі филологиясының негіздері / А.С. Аманжолов. - Алматы: Mектеп, 2012. - 344 б.

[10] Жеменей И. Түркі хальқтары ддебиеті тарихына кіріспе: оқу құраль / И. Жеменей. - Алматы: Қазақу университеті, 2019. - 274 б. 3566.

[11] Уәлиханов Ш. Тәңірі / Ш. Уәлиханов.-Алматы: Халықаральқ Абай клубы, 2016. -

[12] Қондыбай С. Арвық̧азақ мифологиясы. Бірінші кітап / С. Қондыбай. - Алматы. Дайк-Пресс, 2004. - 512 б.

[13] Мелиоранский П.М. Об орхонских и енисейских надгробных памятниках с надписями / П.М. Мелиоранский // «Журнал Министерства народного просвещения». - 1898. - ч. СCCXVII, июнь, отд. 2. - C. 262-292.

[14] Ескеева М.Қ. Көне түркі жазба мұраларының лингвофилософияльқ негізі / М.Қ. Ескеева. - Астана: Сарыарқ̧а, 2011. - 320 б.

[15] Айдаров F. Күлтегін ескерткіші. Зерттеунама / Г. Айдаров. - Алмать: Ана тілі, 1995. -232 б.

[16] Жолдасбеков М. Асыл арналар. Зерттеулер, мақалалар / М. Жолдасбеков. Алматы: Жазушы, 1986. - 328 б.

[17] Ислам А. Ұлттық мәдениет контексіндегі дүниенің тілдік суреті (сальсттырмаль-салвастырмаль лингвомәдени сараптама): «10.02.19 - Тіл теориясыл» филол.вьлл.докт. авторефераты / А. Ислам. - Алматьы, 2004. - 50 б.

[18] Древнетюркский словарь. - Ленинград: Наука, 1969. - 677 с.

[19] Аманжолов А.С. История и теория древнетюркского письма / А.С. Аманжолов. - Aлматы: Meктеп, 2010. - 368 c.

[20] Акишев А.К. Искусство и мифология саков / А.К. Акишев. - Алма-Ата: Наука, 1984. $-176 c$.

[21] Войтов В.Е. Древнетюркский пантеон и модель мироздания в культовопоминальных памятниках Монголии VI-VIIIвв. / В.Е. Войтов. - М.: Изд-во ГМВ, 1996. - 152 с. $256 c$.

[22] Грач А.Д. Древние кочевники в центре Азии / А.Д. Грач. - Москва: Наука, 1980. -

[23] Қайыркен Т.3. Көне түркі ескерткіштеріндегі қзытай жазбалары / T.3. Қайыркен. - Павлодар: Brand print, 2010. - 516 б.

\section{REFERENCES}

[1] Stebleva, I.V. (1972). K rekonstrukcii drevnejurkskoj religiozno-mifologicheskoj sistemy [To reconstruction of the ancient Turkic religious-mythological system]. Tjurkologicheskij sbornik. 1971.-Turkological Collection. 1971.213-226 [in Russian]. 


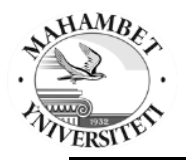

[2] Kljashtornyj, S.G. (1981). Mifologicheskie sjuzhety $v$ drevnetjurkskih pamjatnikah [Mythological plots in ancient Turkic monuments]. Tjurkologicheskij sbornik,1977.- Turkological Collection. 1977.117-138 [in Russian].

[3] Tenishev, Je.R., Dybo, A.V. (Eds.). (2006). Sravnitel'no-istoricheskaja grammatika tjurkskih jazykov. Pratjurkskij jazyk-osnova. Kartina mira pratjurkskogo jetnosa po dannym jazyka[Comparative Grammar of Turkic Languages. The Proto-Turkic basic language. The World Picture of the Proto-Turkic ethnos (by language data)] Moscow: Nauka [in Russian].

[4] Shajmerdinova, N.G. (2014). Drevnetjurkskaja kartina mira v tekstah pis'mennyh pamjatnikov [Ancient Turkic picture of the world in the texts of written monuments]. Astana: ENU[in Russian].

[5] Zhirenov, S.A. (2009). XV-XIV g.g. aqyn-zhyraular pojezijasyndagy «Omir-Olim» konceptisining tanymdyq tabigaty [The Cognitive Nature of the Concept "Life-Death" in the poetry of Akyns and Zhyraus of the 15-19 centuries]. Extended abstract of candidate's thesis. Almaty [in Kazakh].

[6] Abitzhanova, Zh.A. (2009). Orhon-Enisej eskertkishteri tilindegi metaforalardyng uazhdiligi men semantikasy [Motivation and semantics of metaphors in language Orkhon-Yenisei of monuments]. Extended abstract of candidate's thesis. Almaty[in Kazakh].

[7] Zhanuzaqov, T. (Eds.). (2008). Qazaq tilining tusindirme sozdigi [Explanatory dictionary of the Kazakh language]. Almaty:Dajk-Press [in Kazakh].

[8] Qondybaj, S. (2008). Tolyq shygarmalar zhinagy. 12-tom. Argyqazaq mifologijasy. 4kitap.[Complete collections of essays. The mythology of early Kazakhs]. (Vol.4).Almaty: Arys[in Kazakh].

[9] Amanzholov, A.S. (2012). Turki filologijasynyng negizderi [The Bases of Turkic philology]. Almaty: Mektep [in Kazakh].

[10] Zhemenej, I. (2019). Turki halyqtary adebieti tarihyna kirispe [An Introduction to the history of Turkic literature]. Almaty: Qazaq universiteti [in Kazakh].

[11] Ualihanov, Sh. (2016). Tangiri [Tengri]. Almaty: Halyqaralyq Abaj kluby [in Kazakh].

[12] Qondybaj, S. (2004). Argyqazaq mifologijasy. Birinshi kitap [The mythology of early Kazakhs. The first book]. Almaty: Dajk-Press [in Kazakh].

[13] Melioranskij, P.M. (1898). Ob orhonskih i enisejskih nadgrobnyh pamjatnikah $s$ nadpisjami [About Orkhon and Yenisei monuments with inscriptions]. Zhurnal Ministerstva narodnogo prosveshhenija-Journal of the Ministry of Public Education, 2, 262-292 [in Russian].

[14] Eskeeva, M.Q. (2011). Kone turki zhazba muralarynyng lingvofilosofijalyq negizi [Linguistic and philosophical basis of the ancient Turkic written monuments]. Astana: Saryarqa [in Kazakh].

[15] Ajdarov, G. (1995). Kultegin eskertkishi [Kultegin Monument]. Almaty: Ana tili [in Kazakh].

[16] Zholdasbekov, M. (1986). Asyl arnalar. Zertteuler, maqalalar [Living source. Articles and research]. Almaty: Zhazushy [in Kazakh].

[17] Islam, A. (2004). Ulttyq madeniet konteksindegi duniening tildik sureti (salystyrmalysalgastyrmaly lingvomadeni saraptama) [Language denomination of the world in the context of the national culture (comparative-constrastive linguocultural analysis)]. Extended abstract of Doctor's thesis. Almaty [in Kazakh].

[18] Drevnetjurkskij slovar' [Ancient Turkic dictionary]. (1969). Leningrad:Nauka[in Russian].

[19] Amanzholov, A.S. (2010). Istorija i teorija drevnetjurkskogo pis'ma [History and theory of the ancient Turkic writing]. Almaty: Mektep [in Kazakh].

[20] Akishev, A.K. (1984). Iskusstvo i mifologija sakov [The art and mythology of the Sakas].Alma-Ata: Nauka [in Russian]. 


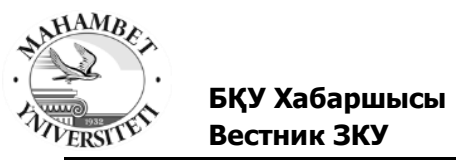

[21] Vojtov, V.E. (1996). Drevnetjurkskij panteon i model' mirozdanija $v$ kul'tovopominal'nyh pamjatnikah Mongolii VI-VIII vv. [Ancient Turkic pantheon and the model of the universe in the cult-memorial monuments of Mongolia in the 6th-8th centuries]. Moscow: Izd-vo GMV [in Russian].

[22] Grach, A.D. (1980). Drevnie kochevniki v centre Azii [Ancient nomads in the center of Asia]. Moskva: Nauka [in Russian].

[23] Qajyrken, T.Z. (2010). Kone turki eskertkishterindegi qytaj zhazbalary [Chinese inscriptions in old Turco monuments]. Pavlodar: Brand print [in Kazakh].

\section{Салқынбай А.Б., Каспихан Б.К. КОНЦЕПТ «ЖИЗНЬ» В ДРЕВНЕТЮРКСКИХ ПИСЬМЕННЫХ ПАМЯТНИКАХ}

Аннотация. В данной статье рассматривается концепт «Жизнь» в древнетюркских письменных памятниках. В статье рассматривается репрезентация концептов «Жизнь» и «Смерть». Распространенная понятие «Мировое дерево» в познаний человечества является моделью древнетюркского концепта «Жизнь» и демонстрирует трехмерную модель мира и пантеон тюркского божества. В древнетюркских письменных памятниках покравителем подземного мира является Ерклиг, а в среднем мире Умай ана и божественный Жер-Су, в верхним миром владеет Тенгри. В рунических памятниках древнетюркского письма концепт «Смерть» состоит из таких языковых единиц: öltig, adïriltïm, kärgäk bol, uča bar.В статье систематизируется философские убеждения о смерти тюркских народов в основе материалов древнетюркских письменных памятников.

Ключевые слова: древнетюркские памятники; Мировое дерево; концепт; жизнь; смерть.

\section{Salkynbai Anar, Kaspikhan Bauyrzhan \\ CONCEPT OF "LIFE" IN ANCIENT TURKIC INSCRIPTIONS}

Abstract. In this article the concept of "Life" is considered in ancient turkic inscriptions. In this article authors considered the representation of the concepts "Life" and "Death". The widespread concept of the "World tree" is a model of the ancient turkic concept "Life" and demonstrates a three-dimensional model of the world and the pantheon of the turkic deity. In ancient turkic written inscriptions Erklig is the patron of the underworld and in the middle world Umay ana and the divine Zher-Su, in the upper world Tengri owns. In the ancient turkic written inscriptions the concept "Death" consists of linguistic units: öltig, adiririltïm, kärgäk bol, uča bar.The article systematizes the philosophical beliefs about the death of the turkic peoples based on the materials of the ancient turkic written inscriptions.

Key words: ancient turkic inscriptions; World Tree; concept; life; death. 